УдК 616.31- 089.444

DOI 10.11603/2411-1597.2021.2.12292

\title{
ОСОБЛИВОСТІ ТА ПОШИРЕНІСТЬ ПРОЯВУ ПРОФЕСІЙНОГО ВИГОРАННЯ МЕДИЧНИХ ПРАЦІВНИКІВ НАРКОЛОГІЧНИХ І ПСИХІАТРИЧНИХ ЗАКЛАДІВ ЛУГАНСЬКОЇ ОБЛАСТІ ЗА СУЧАСНИХ УМОВ
}

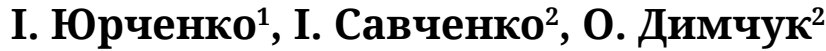 \\ ${ }^{1}$ Комунальне некомериійне підприємство Луганської обласної ради \\ "Центр психічного здоров'я" \\ ${ }^{2}$ Тернопільський національний медичний університет \\ імені І. Я. Горбачевського МОЗ Украӥни
}

У статті проаналізовано та підсумовано результати практичних досліджень поширення професійного вигорання у медичних працівників психіатричних і наркологічних закладів Луганської області та розглянуто основні причини та фактори, що спричиняють розвиток даного захворювання.

\section{FEATURES AND PREVALENCE OF PROFESSIONAL BURNING OF MEDICAL WORKERS OF NARCOLOGICAL AND PSYCHIATRIC INSTITUTIONS OF THE LUHANSK REGION IN MODERN CONDITIONS}

\author{
I. Yurchenko', I. Savchenko², O. Dymchuk ${ }^{2}$ \\ ${ }^{1}$ Municipal non-profit enterprise of Luhansk Regional Council «Mental Health Center» \\ ${ }^{2}$ I. Horbachevsky Ternopil National Medical University
}

The article analyzes and summarizes the results of practical studies of the prevalence of burnout in medical workers of psychiatric and drug treatment facilities in Luhansk region and considers the main causes and factors that cause the development of this disease

Вступ. Вивченню психологічної складової роботи фахівців, які за своєю діяльністю безпосередньо контактують з людьми, в тому числі й медичних працівників, присвячено багато різноманітних досліджень. Одним з аспектів таких досліджень $є$ вивчення феномена синдрому емоційного вигорання як захисної психологічної реакції на надмірні емоційні навантаження при виконанні своїх професійних обов'язків. Вже доведено та неодноразово озвучено, що професійне вигорання - це соціокультурний феномен нашої сучасності, який щороку поглиблюється впродовж останніх десятиліть, а особливо в період початку реформи охорони здоров'я (останні 3 роки) та інтенсивного розповсюдження пандемії COVID-19.

Значна частина робіт присвячена визначенню і вивченню цього феномена у лікарів різних спеціальностей, розробці рекомендацій щодо його корекції та профілактики [1]. Уже з'явилися дослідження

(ㄱ. Ю. Юрченко, І. Савченко, О. Димчук, 2021 щодо виявлення синдрому емоційного вигорання (CEB) у медичних сестер загалом, проте CEB у медсестер, які працюють в різних галузях медицини, досліджений недостатньо. Практично не розкрито питання СЕВ у медичних сестер в такій емоційно витратній галузі медицини, як психіатрія та наркологія. Зміни психологічного стану медичних сестер впливають на їхнє ставлення до пацієнтів, поводження з хворими, а отже, насамперед, на якість надання психіатричної та наркологічної допомоги.

Порівнюючи із зарубіжними публікаціями і дослідженнями, стан наукової проблеми в нашому суспільстві вимагає нових більш розгорнутих і поглиблених теоретичних і емпіричних досліджень, зважаючи на весь спектр культурно-історичних, соціально-політичних умов та індивідуальних особливостей професійної діяльності.

У зв'язку з цим, актуальним стає вивчення соціальних і психологічних характеристик у медичних 
сестер психіатричних установ (особливо за умов реформування та переосмислення психіатричної допомоги в Україні, зокрема в Луганській області), для того, щоб оптимізувати їхню роботу, сформувати положення щодо профілактики емоційного вигорання і корекції цих проявів у фахівців середньої ланки.

Основна частина. Всесвітня організація охорони здоров'я (ВОО3) визнала, що синдром емоційного вигорання $\epsilon$ проблемою, яка потребує медичної уваги. Згідно з визначенням ВООЗ (2001), «синдром вигорання (burnout syndrome) - це фізичне, емоційне або мотиваційне виснаження, що характеризується порушенням продуктивності в роботі та втомою, безсонням, підвищеною схильністю до соматичних захворювань, а також вживанням алкоголю або інших психоактивних речовин з метою одержати тимчасове полегшення, що має тенденцію до розвитку фізіологічної залежності і (у багатьох випадках) суїцидальної поведінки. Цей синдром звичайно розцінюється як стрес-реакція у відповідь на безжалісні виробничі та емоційні вимоги, що відбуваються через надмірну відданість людини своїй роботі 3 супутньою цьому зневагою до сімейного життя або відпочинку» [2].

Актуальність дослідження особливостей синдрому емоційного вигорання у медичних сестер пов'язана з масовими проявами цього патологічного стану серед медичних працівників. Інтенсифікація професійної діяльності, розширення переліку обов'язків, високе виробниче навантаження, цілодобові чергування медичних сестер - всі ці фактори призводять до розвитку психоемоційного напруження. На фахівців середньої ланки покладають велику відповідальність за життя і здоров'я людини, що спричиняє ризик виникнення CEВ. В Україні з 1 квітня 2020 р. стартувала реформа системи охорони здоров'я на вторинному та третинному рівнях надання медичної допомоги, яка викликала бурхливу реакцію серед медичних працівників, страйки і навіть оголошення про голодування лікарів, оскільки такі зміни передбачають досить жорсткі обмеження у фінансуванні вторинної ланки та масове звільнення фахівців. Тому до виробничих несприятливих умов приєднався фактор невпевненості у завтрашньому дні, невідповідність між запитом і можливостями медичної служби.

Фінансування психіатричних лікарень, отримане від Національної служби здоров'я України (НСЗУ), на період із 1 квітня до 31 грудня 2020 р., у середньому зменшено вдвічі порівняно з відповідним періодом минулого року.

Проте особливу стурбованість викликали повідомлення про скорочення 3164 штатних посад і 2446 фізичних осіб - працівників закладів із надання психіатричної допомоги, а саме: 197 лікарів; 661 медичну сестру; 1237 молодших медичних сестер і 390 фізичних осіб іншого персоналу, серед яких і психологи. Крім того, 776 працівників переведено на неповний робочий день, серед них - 169 лікарів, 188 медичних сестер, 309 молодших медичних сестер і 119 інших фахівців. Вивчаючи інформацію на сайті НСзУ щодо розподілу фінансів між закладами для надання стаціонарної психіатричної допомоги, не виявлено відповідної стратегії переходу до нової системи фінансування. За даними МОЗ України (на початок 2019 р.), в Україні нараховувалося 58 психіатричних лікарень і 24 наркологічні стаціонарні заклади зі загальним ліжковим фондом 26517 психіатричних і 3371 наркологічних ліжок. Середній термін перебування в психіатричному стаціонарі - 48,7 дня; наркологічному стаціонарі - 12,3 дня.

Так, пакет медичних гарантій «Психіатрична допомога дорослим та дітям» для надання стаціонарної психіатричної допомоги пацієнтам отримали 194 заклади, серед яких лише 58 психіатричних лікарень. Зокрема, 136 пакетів медичних гарантій «Психіатрична допомога дорослим та дітям» отримали наркологічні лікарні. Це попри заяву Національної служби здоров'я України про відсутність окремого пакета для фінансового забезпечення стаціонарної наркологічної допомоги [3].

Тому сьогодні керівники лікувальних закладів із надання психіатричної та наркологічної допомоги стикаються із цими викликами щодо реорганізації медичної служби, маючи при цьому вже достатньо виснажених та зневірених медичних працівників.

Виникнення СЕВ зумовлено спільною дією зовнішніх та внутрішніх факторів. Проаналізувавши особливості цих факторів у медичних працівників Луганської області, можна відзначити таке: на першому місці у переліку зовнішніх умов, що призводять до розповсюдження CEB, є збільшення навантаження через скорочення штату. Крім того, до організаційних факторів можна віднести і невизначеність зі заробітною платою, малу ефективність наслідків реорганізації трудового процесу.

До хронічних факторів впливу на розвиток СЕВ сміливо можна віднести, по-перше, стреси через 
постійну невизначеність щодо взаємовідносин із НСЗУ, по-друге, збройний конфлікт на території Луганської області (тривоги через ескалацію військових дій, страх за близьких, які перебувають в лавах 3бройних сил України або на окупованій території), по-третє, житлові та фінансові проблеми (12,9% опитаних медичних працівників мають статус внутрішньо переміщених осіб), і лише, наприкінці - інтенсивне спілкування з контингентом пацієнтів підвищеної складності.

До інших зовнішніх факторів можна віднести напруженість в робочому процесі через поширеність пандемії (в тому числі вимушене обмеження спілкування або хвороба, чи то навіть смерть близьких та знайомих через COVID-19), відсутність підтримки в родині, або ж в сім'ї $\epsilon$ хвора на хронічні захворювання людина, яка потребує постійного догляду та уваги тощо.

Зважаючи на вищевказане, такі внутрішні передумови, як інтенсивна інтеріоризація, фрустрація мотивації, наявність особистих якостей медичного працівника, хоча і мають важливе значення, але відходять на другий план.

Проведена дослідницька робота серед молодших фахівців із медичною освітою та лікарів, які надають стаціонарну або амбулаторну психіатричну та наркологічну допомогу мешканцям Луганської області. Це були співробітники КНП лОР «Сватівська обласна лікарня з надання психіатричної допомоги» - 350 ліжок, КНП ЛОР «Лисичанська обласна лікарня з надання психіатричної допомоги» - 70 ліжок, КНП ЛОР «Центр психічного здоров'я» - 60 ліжок, психоневрологічного відділення КНП «Сєвєродонецька міська багатопрофільна лікарня» - 30 ліжок, медичні сестри наркологічних та психіатричних кабінетів, психоневрологічних інтернатів.

Обстежено 93 особи методом когнітивного дослідження (опитування + вибіркове інтерв'ю за бажанням респондента - 11 осіб + спостереження).

Відповідно до виявлених статистичних даних щодо респондентів, встановлено, що серед них $15 \%$ - лікарі, 85 \% - медичні сестри та брати. Вищу освіту мають 16,2 \%, 15 \% - незакінчену вищу освіту, 68,8 \% - медичний фаховий коледж. При цьому 20,43 \% мають стаж роботи в медичній галузі до 5 років, від 5 до 10 років - 18,3 \% від опитаних, 15,05 \% мають медичний стаж від 10 до 15 років, 16,1 \% - від 15 до 20 років. Більша частина респондентів має як життєвий досвід, так і професійну ква- ліфікацію: 49,4 \% - вищу категорію, 29,2 \% - першу категорію, 11,8 \% - другу категорію. І лише 8,6 \% респондентів не мають жодної кваліфікаційної категорії.

За місцем проживання респондентів поділяють таким чином: 40,8 \% проживають у місті (від 50 тис. населення), 17,2 \% - в селі та 42,0 \% є жителями селища, передмістя або невеликого містечка (до 30 тис. населення).

Поділ за соціальним статусом медичних працівників, які брали участь в опитуванні, $\epsilon$ таким: 17,2 \% - розлучені, 3,22 \% - вдівці, 5 \% - бездітні. Чоловіків - лише 6 \% зі загальної кількості опитаних. Цікаво, що через скорочення штату, працівників пенсійного віку стало набагато менше - всього 4,3 \%, і в основному це лікарі, які продовжують професійну діяльність через гостру нестачу фахівців із лікувальної справи у регіоні та низький рівень пенсійного забезпечення.

За фінансовим забезпеченням: $14 \% \in$ основними утримувачами і забезпечують 100 \% доходу своєї сім'i, 67,73 \% забезпечують приблизно половину бюджету, 18,27 \% - менше половини бюджету, 10,75 \% працюють понаднормово або за сумісництвом, 3 опитаних лише 8,6 \% вагалися з відповідями.

Проведено анонімне опитування респондентів на основі методики В. В. Бойко для оцінки рівня емоційного вигорання, що виникає у людини в процесі виконання різних видів діяльності, пов'язаних із тривалим впливом ряду несприятливих стрес-факторів. Запропонована методика дає докладну картину синдрому емоційного вигорання як динамічного процесу, що виникає поетапно у повній відповідності до механізму розвитку стресу. Рівень емоційного вигорання оцінюють за 12 шкалами, що відповідають трьом фазам:

1. Фаза «Напруження» - передвісник і «пусковий механізм» у формуванні емоційного вигорання. Напруження має динамічний характер, що зумовлено вимотуючою постійністю або посиленням дії психотравмуючих чинників.

2. Фаза «Резистенція» - опір наростаючому стресу.

3. Фаза «Виснаження» - характеризується більш або менш вираженим падінням енергетичного тонусу і ослабленням нервової системи [4].

Відповідно до опитувальника В. В. Бойко, виявлено, що $12 \%$ респондентів перебувають на рівні виснаження, у 34 \% фаза резистенції формується або вже сформована. Високий рівень деперсоналізації виявлено в $13 \%$ респондентів, а 41 \% перебуває в 
процесі її формування. 60 \% відповіли на питання, що визначають високий рівень редукції в професійній діяльності. За результатами опитування, 2 \% (а завдяки інтерв'ю визначено, що це відверті відповіді) підтверджують дуже низький рівень редукції та втрату інтересу до професії.

Важливим психодіагностичним інструментарієм в цьому опитуванні виступив опитувальник МBI авторів К. Маслач і С. Джексона (Maslach Burnout Inventory). К. Маслач виділяє чотири стадії вигорання, які характеризують: 1) ідеалізм і надмірні вимоги до себе; 2) емоційне та психічне виснаження; 3) дегуманізація як спосіб захисту; 4) синдром огиди (до себе - інших - до всього) [5]. Цікаво, що, аналізуючи відповіді на ці два опитувальника, не важко було виокремити відверті відповіді та деяку нещирість респондентів. Якщо в першому варіанті багато медичних працівників намагалися приховати свої проблеми і відповідали з бажанням прикрасити або применшити існуючі проблеми, то в другому - несвідомо відповідали на питання більш щиро та відверто. За опитувальником К. Маслач, 24,3 \% респондентів мають високі показники виснаження та всі ознаки CEB; 17,9 \% - визнають прояви відвертої байдужості до своїх професійних обов'язків; $21 \%$ опитаних медичних працівників не мають жодних планів на майбутнє.

Найбільший відсоток СЕВ спостерігають у респондентів із медичним стажем від 15 років і більше, найвищий рівень деперсоналізації відзначають у респондентів, старших 50 років, які мають виробничий стаж більше 20 років.

Третій варіант опитувальника, що використовували при дослідженні, створений на основі опитувальника WHO проекту GENAHTO, що був у свій час розповсюджений на території Луганської та Донецької областей та допомагає виявити приховані проблеми респондента (алкоголізація, приймання психоактивних речовин, схильність до депресії, хронічна незадоволеність тощо). Опитувальник був абсолютно анонімний, охоплював вивчення таких проблем, як соціальний статус та рівень матеріальних статків та заробітків сім'ї, алкоголізація в суспільстві та з чим це пов'язано, соціальні та психологічні проблеми внутрішньо переміщених осіб, реакція на суспільнополітичні катаклізми тощо. Це дозволило провести своєрідний локус-контроль серед респондентів та виявити досить цікаві, а скоріше тривожні цифри. Наприклад, почуття самотності (постійне) підтвер- джують 20,43 \% опитаних, алкоголізуються - 6,4 \%, при цьому 8,6 \% респондентів зовсім відмовилися відповідати на питання цього блоку; 3,22 \% обстежених визнають прояви агресії до рідних та близьких, 5,7 \% незадоволені станом свого фізичного здоров'я, а 13,9 \% - станом психічного здоров'я. Серед опитаних 16,3 \% часто приймають психотропні, снодійні або знеболювальні препарати, не за призначенням лікаря, для зменшення проявів безсоння, стресу чи втоми. 52,9 \% опитаних відчувають тривогу, а 13 \% з них відмовилися відповідати. Але при бесіді (інтерв'ю) визнали, що живуть з почуттям тривоги постійно і вже звикли до цього стану. До речі, найменший відсоток деперсоналізації у респондентів, які проживають у сільській місцевості.

Основна кількість респондентів - це дійсно професіонали і люди, віддані своїй професії, своїй спеціальності. Але 18,4 \% з них зверталися за допомогою для вирішення особистих психологічних проблем: 2,2 \% - до психіатра, 4,3 \% - до психолога, 2,2 \% - до священика, а 9,7 \% потребували підтримки та допомоги друзів, сусідів.

Виробниче навантаження медичних сестер, цілодобовий режим роботи з обов'язковими чергуваннями, очікування ускладнень в стані хворих вимагають високої функціональної активності організму медичної сестри і можуть бути кваліфіковані як провідні патогенні професійні чинники. Крім того, обтяжуючий вплив на здоров'я працюючих спричиняє контакт з хворими на хронічні захворювання, коли медичний працівник не бачить позитивних результатів своїх зусиль з порятунку хворого і нерідко відчуває власне безсилля. У результаті часто розвиваються церебральні порушення у формі неврозу, соматовісцеральні порушення у вигляді гіпертензії, стенокардії, виразкових уражень шлунково-кишкового тракту [6].

Діяльність медичного працівника в психіатрії або наркології часто припускає тривале перебування в дискомфортних умовах і ситуаціях. Важливою особливістю роботи в психіатричних закладах $\epsilon$ тісне та інтенсивне спілкування з пацієнтами з хронічним перебігом захворювання та втраченими соціальними зв'язками і навичками, довготривалим перебуванням у стаціонарних умовах. При сучасному навантаженні медичних працівників і введенні в їх роботу нових програм, підходів та вимог проблемою $\epsilon$ не те, що працівник емоційно вигорає, оскільки це $\epsilon$ природний процес. Проблема полягає в тому, що 
він не вміє це вчасно помічати в коловерті сучасного інформаційного простору, постійних нововведень та змін.

Висновки. Досліджені взаємозв'язки між емоційним вигоранням та життєвими орієнтаціями і емоційною спрямованістю у медичних працівників

\section{СПИСОК ЛІТЕРАТУРИ}

1. Постнов В. В. Профилактика синдрома эмоционального сгорания у врачей психиатров-наркологов: пособие для врачей и психологов / В. В. Постнов, В. А. Дереча, В. В. Карпец. - М.; Оренбург, 2003. - 32 с.

2. Юрьева Л. Н. Профессиональное выгорание у медицинских работников / Л. Н. Юрьева. - К., 2004. - 271 с.

3. Пінчук І. Безпрецедентність кризи в українській психіатрії / І. Пінчук // Нейрonews - психоневрологія та нейропсихіатрія. - 2020. - № 4 (115). - 5 с.

4. Орел В. Е. Феномен «выгорания» в зарубежной психологии : эмпирические исследования и перспективы / психіатричної сфери підтверджують, що в розвитку синдрому емоційного вигорання мають значення багато факторів - від стресостійкості та індивідуальних особливостей особистості до соціально-політичних рішень, що впливають не лише на майбутнє країни чи області, а й на буденне життя.

В. Е. Орел // Психологический журнал. - 2001. - Т. 22, № 1. - C. 34-42.

5. Maslach C. Burnout: A social psychological analysis. In The Burnout syndromeed / C. Maslach. - IL: London House, 1982.

6. Swensen S. Physician organization collaboration reduces physician burnout and promotesengagement: the Mayo Clinic experience / S. Swensen, A. Kabcenell, T. Shanafelt // J. Health Manag. - 2016. - Vol. 61, No. 2. - P. 105-127. PMID: https://pubmed.ncbi.nlm.nih.gov/27111930/. 